\title{
Dominika Walkiewicz
}

Uniwersytet Ekonomiczny we Wrocławiu

e-mail: dominikawalkiewicz@tlen.pl

\section{ATRAKCYJNOŚĆ REGIONÓW A LOKALIZACJA SPECJALNYCH STREF EKONOMICZNYCH}

ATTRACTIVENESS OF REGIONS VS. LOCATION OF SPECIAL ECONOMIC ZONES

DOI: $10.15611 / \mathrm{pn} .2017 .467 .20$

JEL Classification: H21, H25, H30, H32

Streszczenie: Specjalne strefy ekonomiczne są instrumentem interwencjonizmu państwowego funkcjonującym na terenie Polski od 1994 roku. Powstały w celu restrukturyzacji regionów zacofanych i borykających się z osłabieniem po przejściu z gospodarki centralnej do rynkowej. Z czasem jednak strefy przestały spełniać swoje podstawowe zadanie, a stały się elementem przetargowym przyciągającym inwestorów. Coraz częściej podstrefy tworzone są poza rejonem strefy w wyniku nacisku grup interesu na terenach wysoko rozwiniętych o dużej atrakcyjności. Celem artykułu jest wyjaśnienie tak dużego rozproszenia podstref specjalnych stref ekonomicznych w Polsce i wstępne przybliżenie skutków ich lokalizacji w regionach najbardziej atrakcyjnych. W artykule do analizy atrakcyjności regionów zastosowano metodę punktacji w umownej skali liczbowej z użyciem wybranego systemu oceniania. Następnie wyniki poddano analizie porównawczej. Okres badawczy to rok 2014, dla którego określono wartości wybranych parametrów. Przedmiotem badania są województwa w Polsce oraz podstrefy polskich stref ekonomicznych ze szczególnym uwzględnieniem ich lokalizacji.

Słowa kluczowe: specjalna strefa ekonomiczna, atrakcyjność regionów, podstrefa, lokalizacja.

Summary: Special economic zones are means of interventionism which have been functioning since 1994 in Poland. They were established in order to restructure and reorganize backward regions which were facing a serious crisis after the transformation from centrally planned to market economy. With time, zones changed their main function and began being an inducement for investors. The research indicates that, more often, subzones are established in very attractive areas with a high level of development. The purpose of this article is to explain such a wide dispersion in the location of subzones of special economic zones in Poland and preliminary to show the effects for regions. The author uses the point method to rate the attractiveness of regions with agreed scale and parameters. Then, the results are compared. The study covers a situation in 2014 and evaluates voivodships in Poland with the subzones of special economic zones with emphasis on their locations.

Keywords: special economic zones, region attractiveness, subzone, location. 


\section{Wstęp}

W Polsce działa 14 specjalnych stref ekonomicznych i aż 368 podstref, które charakteryzują się dużym rozproszeniem. Powodem tego mogą być wysokie koszty tworzenia nowej strefy, które znacznie przewyższają ustanowienie nowych obszarów stref już istniejących. Koncepcja powstawania stref ekonomicznych zrodziła się już w czasach rzymskich w postaci wolnych portów. Za pierwszą strefę ekonomiczną uznaje się strefę w Puerto Rico utworzoną w 1951 roku. Należący do niej mogli korzystać z przywileju bezcłowego handlu. Polska koncepcja stworzenia stref uprzedmiotowiła się jako „Euro-Park Mielec” w 1995 r. [Przewodnik po specjalnych strefach...]. W wyniku transformacji systemowej w Polsce po 1989 r. istniało wiele regionów borykających się z osłabieniem gospodarczym, dużym bezrobociem, zwłaszcza strukturalnym, kryzysami lub bankructwem zakładów produkcyjnych, niedoborem kapitału i zachęt inwestycyjnych. SSE w Mielcu powstała jako sposób na stworzenie nowych miejsc pracy oraz zagospodarowanie pozostałej infrastruktury. Aby stało się to możliwe, niezbędne było przyciągnięcie inwestorów. Sposobem na to miała się okazać preferencyjna polityka podatkowa na terenie strefy. Brak działania ze strony państwa mógłby powodować regres w sferze zarówno gospodarczej, jak i społecznej [Nowakowska 2009].

Tabela 1. Specjalne strefy ekonomiczne w Polsce

\begin{tabular}{|l|c|c|}
\hline \multicolumn{1}{|c|}{ Strefa } & Rok powstania & Liczba podstref \\
\hline „Euro-Park Mielec” & 1995 & 28 \\
\hline Katowicka Specjalna Strefa Ekonomiczna & 1996 & 4 \\
\hline Suwalska Specjalna Strefa Ekonomiczna & 1996 & 18 \\
\hline Legnicka Specjalna Strefa Ekonomiczna & 1997 & 20 \\
\hline Łódzka Specjalna Strefa Ekonomiczna & 1997 & 44 \\
\hline Wałbrzyska Specjalna Strefa Ekonomiczna „Invest-Park” & 1997 & 48 \\
\hline Częstochowska Specjalna Strefa Ekonomiczna & 1997 & - \\
\hline $\begin{array}{l}\text { Kamiennogórska Specjalna Strefa Ekonomiczna Małej Przedsię- } \\
\text { biorczości }\end{array}$ & 1997 & 16 \\
\hline Kostrzyńsko-Słubicka Specjalna Strefa Ekonomiczna & 1997 & 44 \\
\hline Słupska Specjalna Strefa Ekonomiczna & 1997 & 18 \\
\hline Specjalna Strefa Ekonomiczna „Starachowice” & 1997 & 15 \\
\hline $\begin{array}{l}\text { Tarnobrzeska Specjalna Strefa Ekonomiczna „EUROPARK } \\
\text { WISŁOSAN” }\end{array}$ & 1997 & 21 \\
\hline Specjalna Strefa Ekonomiczna „Tczew” & 1997 & - \\
\hline Warmińsko-Mazurska Specjalna Strefa Ekonomiczna & 1997 & 30 \\
\hline Specjalna Strefa Ekonomiczna „Żarnowiec” & 1997 & - \\
\hline Specjalna Strefa Ekonomiczna „Krakowski Park Technologiczny” & 1998 & 32 \\
\hline Mazowiecka Specjalna Strefa Ekonomiczna „Technopark-Modlin” & 1998 & - \\
\hline Pomorska Specjalna Strefa Ekonomiczna & 2001 & 30 \\
\hline
\end{tabular}

Źródło: opracowanie własne na podstawie Informacja o realizacji ustawy o specjalnych strefach ekonomicznych. Stan na 31 grudnia 2015 r. 
W tabeli 1 przedstawiono w porządku chronologicznym specjalne strefy ekonomiczne w Polsce wraz z liczbą podstref należącą do danej strefy (stan na rok 2014). Najwięcej obszarów należy do Wałbrzyskiej SSE „Invest-Park”, która obejmuje aż 48 podstref w 4 województwach.

\section{Istota stref uprzywilejowanych}

Specjalną strefę ekonomiczną definiuje się jako wyodrębnioną, niezamieszkałą część terytorium danego kraju, w której dla podmiotów prowadzących działalność gospodarczą istnieją preferencyjne warunki [Ustawa z dnia 20 października 1994 r.]. Z warunków tych korzystać mogą inwestorzy spełniający następujące wymogi [Jurkiewicz 2015]:

- dochód, który podlega zwolnieniu z podatku dochodowego musi być wypracowany na terenie strefy ekonomicznej,

- działalność na terenie strefy jest realizowana na podstawie wydanego zezwolenia,

- działalność gospodarcza danego podmiotu oraz składniki majątkowe, na które poczyniono nakłady inwestycyjne, będą utrzymywane dłużej niż 5 lat.

Specjalne strefy ekonomiczne stanowią specyficzną konstrukcję pod względem zarówno prawnym, jak i politycznym. Na ich terenie bowiem nie obowiązują krajowe przepisy regulujące działalność gospodarczą [Kryńska 2000]. Podstawową regulacją prawną jest Ustawa z dnia 20 października 1994 r. o specjalnych strefach ekonomicznych.

Obszar stref limitowany jest ustawą i przystosowany do wymogów wspólnotowych. Do 2004 roku limit maksymalny wynosił 6325 ha. Przez kolejno dwa lata był podwyższany do 8000 ha, 12000 ha i obowiązujący do teraz wynosi 20000 ha. Podmiotem odpowiedzialnym za tworzenie planów rozwoju stref, udzielanie i zmiany zezwoleń jest minister właściwy do spraw gospodarki [Lichota 2016].

\subsection{Cele tworzenia stref ekonomicznych}

Do głównych przesłanek ustanawiania stref zalicza się następujące:

- odnowa i rewitalizacja terenów poprzemysłowych,

- dywersyfikacja prowadzonej działalności na określonych terenach,

- zwiększanie innowacyjności i inwestycji w B+R,

- pobudzanie działalności inwestycyjnej,

- wzrost zatrudnienia, zwiększanie kwalifikacji pracowniczych,

- generowanie PKB w poszczególnych regionach,

- wzrosty wpływów budżetowych w postaci podatku VAT,

- redukcja zasiłków dla bezrobotnych przez tworzenie nowych stanowisk pracy.

Strefy ekonomiczne mają więc odgrywać rolę katalizatora procesów rozwijających region w aspekcie zarówno gospodarczym, jak i społecznym. 


\subsection{Korzyści i koszty stref uprzywilejowanych}

Ogólne korzyści wynikające z funkcjonowania stref ekonomicznych to:

- wpływy budżetowe z podatku VAT, podatku dochodowego od osób fizycznych i prawnych,

- wpływy do budżetu JST z podatku od nieruchomości,

- redukcja wydatków na zasiłki dla bezrobotnych oraz składek na ubezpieczenie społeczne,

- wykorzystanie niezagospodarowanych zasobów z zachowaniem zasad zrównoważonego rozwoju,

- rozwój eksportu,

- wzrost zaawansowania technologicznego i technicznego regionu,

- wzrost zatrudnienia kobiet.

Przywileje, jakie stoją po stronie inwestora, to: pomoc w formalnościach związanych z prawem budowlanym, co znacznie przyspiesza realizację inwestycji, uzbrojony grunt wyposażony $\mathrm{w}$ dogodną infrastrukturę po konkurencyjnej cenie czy zwolnienie z podatku od nieruchomości [Ajchel 2016].

Do kosztów finansowych należą:

- wydatkowanie środków na udzielenie pomocy publicznej,

- koszty związane z przygotowanie terenów, w szczególności modernizacja infrastruktury,

- rezygnacja z wpływów wynikających z podatku dochodowego od spółek zarządzających strefami uprzywilejowanymi,

- koszty na administrację związaną z kontrolowaniem i nadzorowaniem stref.

Jednakże, mimo zmniejszonych wpływów budżetowych z tytułu podatku dochodowego, finalnym rezultatem są korzyści budżetowe. Przejawiają się w postaci wzrostu wpływów z podatku PIT od osób zatrudnionych.

\section{Cel i metodyka badań}

J. Brdulak już w 1999 r. zauważył, że przywileje podatkowe wynikające z działalności w specjalnej strefie ekonomicznej nie są najważniejszym czynnikiem przyciągającym inwestorów. W podjęciu decyzji o konkretnej lokalizacji inwestorzy biorą pod uwagę wiele innych dodatkowych uwarunkowań. Uprzywilejowanie podatkowe stanowi jedynie argument przetargowy podwyższający atrakcyjność regionu, a nie stanowiący podstawę decyzyjną [Brdulak 1999].

Tworzenie podstref $\mathrm{z}$ inicjatywy inwestora nasiliło się po nowelizacji ustawy o specjalnych strefach ekonomicznych w 2000 r. [Ustawa z dnia 16 listopada 2000 r.]. Zmiany obejmowały możliwość wyłączenia $\mathrm{z}$ terenu strefy obszarów nieużytkowych, takich jak lasy, drogi, i włączenie do strefy działek z zupełnie innej gminy w całej Polsce. Dało to duże możliwości do ustanawiania stref w dowolnie wybranej lokalizacji. Potencjalni inwestorzy stali się grupą nacisku, dążącą do obejmowania 
strefą obszarów najbardziej atrakcyjnych, w których dodatkowo będą mogli korzystać ze zwolnień podatkowych.

Paradoksalnie strefy ekonomiczne, które z założenia miały przyspieszać rozwój regionów słabszych, lokowane są na terenach atrakcyjnych dla inwestora. To inwestycje zagraniczne determinują lokalizację obszarów strefowych, a nie, jak zakładano, strefy uprzywilejowane przyciągają inwestorów [Ambroziak 2009]. Trafnym przykładem jest Katowicka SSE. W 83\% strefę tworzą tereny miast Gliwice, Tychy i Bielsko-Biała. Jedynie 7\% stanowią tereny o wysokim bezrobociu i monokulturalnej gospodarce [Domański 2005].

Celem badania było wyjaśnienie tak dużego rozproszenia podstref specjalnych stref ekonomicznych w Polsce i wstępne przybliżenie skutków ich lokalizacji w regionach najbardziej atrakcyjnych. Przeprowadzono analizę atrakcyjności regionów pod względem podejmowania inwestycji w specjalnych strefach ekonomicznych. Teza postawiona przez autora brzmi: im bardziej atrakcyjny jest region, tym więcej w nim obszarów specjalnych stref ekonomicznych. Do badania wybrano 15 województw w Polsce. Województwo mazowieckie, ze względu na wartości skrajne, odstające od pozostałych, nie było brane pod uwagę.

Zastosowano metodę punktacji każdego regionu w skali liczbowej 6, 8, 10 punktów. Skala ta jest prosta w obliczeniach i pozwala już przy pierwszym porównaniu wyników zauważyć dysproporcje wybranych wskaźników. Szczególną uwagę poświęcono regionom najbardziej atrakcyjnym, dlatego punktowane były jedynie trzy najbardziej pożądane wartości parametrów.

Parametry analizy określono jak poniżej:

- Struktura gospodarki w postaci wielkości PKB według sektorów gospodarki ${ }^{1}$. Sektor przemysłowo-produkcyjny był najbardziej pożądany, następnie handel i usługi. Najmniej pożądane było rolnictwo. Zezwolenia wydawane są głównie firmom produkcyjnym, a także usługowym w zakresie programowania, hostingu, zarządzania, doradztwa, audytu finansowego, księgowości, badań i analiz, centrów telefonicznych.

- Kapitał ludzki mierzony liczbą uczelni wyższych, absolwentów studiów magisterskich, inżynierów. Obliczono również wskaźnik udziału absolwentów studiów wyższych do ogółu liczby ludności. Im wyższe wielkości, tym większa atrakcyjność regionu.

- Koszty pracy na 1 zatrudnionego miesięcznie. Wielkości najmniejsze są najbardziej pożądane przez inwestorów.

- Infrastruktura rozpatrywana w zakresie długości autostrad i dróg ekspresowych, liczby portów lotniczych.

- Działalność innowacyjna mierzona wysokością nakładów.

- Instytucje otoczenia biznesu: parki technologiczne, inkubatory technologiczne, akademickie inkubatory przedsiębiorczości, inkubatory przedsiębiorczości, centra transferu technologii, klastry.

\footnotetext{
1 Wartości parametrów dotyczą najbardziej aktualnych danych, tj. roku 2012.
} 
W każdym regionie zestawiono ze sobą wartości parametrów i zastosowano odpowiednią punktację. Region osiągający najwyższy/najniższy wskaźnik (w zależności od parametru) otrzymywał 10 punktów, kolejne 8 i 6 punktów. Po zsumowaniu udało się określić region najbardziej i najmniej atrakcyjny pod względem utworzenia podstrefy ekonomicznej.

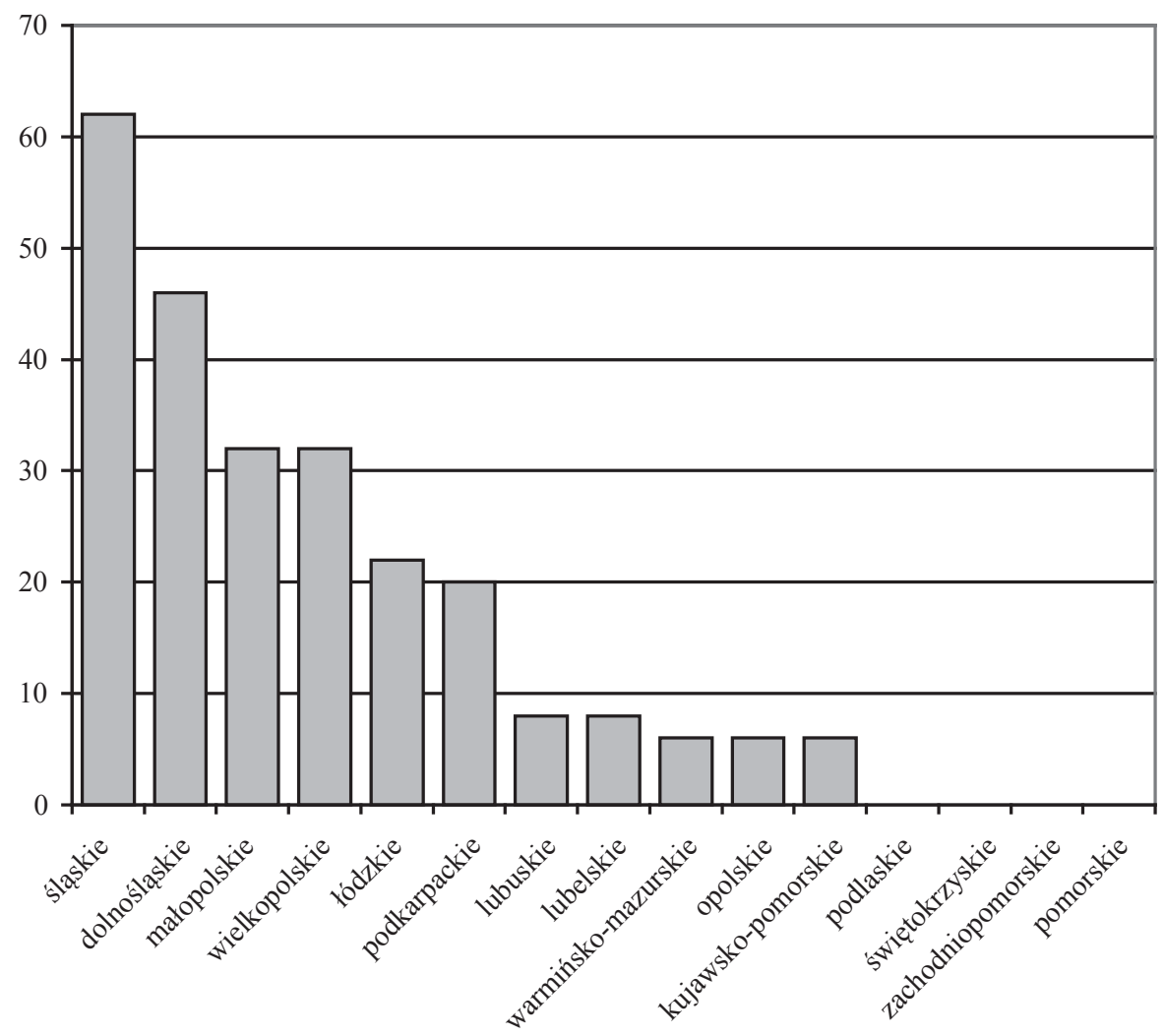

Rys. 1. Atrakcyjność inwestycyjna regionów

Źródło: opracowanie własne.

Najwyższą liczbę punktów uzyskało województwo śląskie (62 punkty). Maksymalnie zostały ocenione parametry dotyczące struktury gospodarki. Dominującym sektorem jest przemysł (63 $853 \mathrm{mln}$ zł). Usługi generują $13346 \mathrm{mln}$ zł, co na tle pozostałych województw jest wartością najwyższą. W regionie tym najwięcej środków przeznaczanych jest na innowacje - ponad 4,2 mln zł. Śląskie dostało maksymalną liczbę punktów również za liczbę uczelni wyższych (41) oraz instytucje otoczenia biznesu (50). W regionie tym w 2014 r. gminy strefowe stanowiły 16\% ogółu gmin, należały one do Katowickiej SSE. 
W analizie powyżej średniej znalazły się województwa:

- Łódzkie (gminy strefowe stanowią 19\% i należą do Łódzkiej SSE oraz SSE Starachowice) osiągając maksymalną liczbę punktów za parametr dotyczący infrastruktury oraz po 6 punktów za nakłady na działalność innowacyjną i strukturę gospodarki.

- Małopolskie, w którym najwyżej oceniony parametr dotyczy kapitału ludzkiego. Liczba absolwentów studiów wyższych do ogółu liczby ludności wyniosła $0,7 \%$. $\mathrm{W}$ tym regionie najwięcej jest również inżynierów. Gminy strefowe stanowią 12\% (Katowicka SSE, Krakowski Park Technologiczny, SSE „Euro-Park Mielec").

- Podkarpackie, w którym odsetek gmin strefowych wynosi 21\%. Najwyżej oceniono najniższe koszty pracy oraz udział rolnictwa w PKB. Na terenie województwa znajdują się podstrefy Krakowskiego Parku Technologicznego, SSE „Euro-Park Mielec” oraz TSSE „Euro-Park Wisłosan”).

- Wielkopolskie (odsetek gmin strefowych: $11 \%$ ). Mimo, że w żadnym z parametrów nie zdobyło maksymalnej liczby punktów, to ich ostateczna suma wyniosła 32.

- Dolnośląskie, które w całej analizie zajęło drugie miejsce (46 punktów). Również w żadnym z parametrów nie zdobyło maksymalnej ilości punktów. Gminy strefowe stanowią aż 33\% ogółu gmin i należą do: Kamiennogórskiej SSE, TSSE Euro Park Wisłosan, Legnickiej SSE i Wałbrzyskiej SSE.

Województwa te charakteryzują się chłonnymi rynkami, wysokim poziomem rozwoju kapitału ludzkiego oraz względnie wysokimi wydatkami na działalność innowacyjną.

Regiony należące do północnej i północno-wschodniej Polski cechują się niską atrakcyjnością. W analizie najmniejszą liczbę punktów zdobyły województwa świętokrzyskie, podlaskie, pomorskie, zachodniopomorskie, lubelskie i kujawsko-pomorskie. W regionach tych najmniejszy był również odsetek gmin strefowych. $\mathrm{W}$ tabeli 2 zestawiono ze sobą parametry analizy dla wybranych województw. Jako parametry wybrano następujące wskaźniki:

1. Liczba uczelni wyższych

2. Absolwenci szkół wyższych do liczby ludności ogółem (\%)

3. Inżynierowie

4. Koszty pracy na 1 zatrudnionego miesięcznie (zł)

5. Długość autostrad i dróg ekspresowych $(\mathrm{km})$

6. Porty lotnicze

7. Nakłady na działalność innowacyjną (zł)

8. Instytucje otoczenia biznesu

9. PKB wypracowane w sektorze rolnictwa ( $\mathrm{mln}$ zl)

10. PKB wypracowane w sektorze przemysłu ( $\mathrm{mln} z \nmid)$

11. PKB wypracowane w sektorze handlu ( $\mathrm{mln} \mathrm{zl})$

12. PKB wypracowane w sektorze usług ( $\mathrm{mln} \mathrm{zl}$ )

Szarością zróżnicowano wartości najwyżej ocenione. 
Tabela 2. Wartości parametrów analizy atrakcyjności inwestycyjnej w województwach Polski w 2014 roku

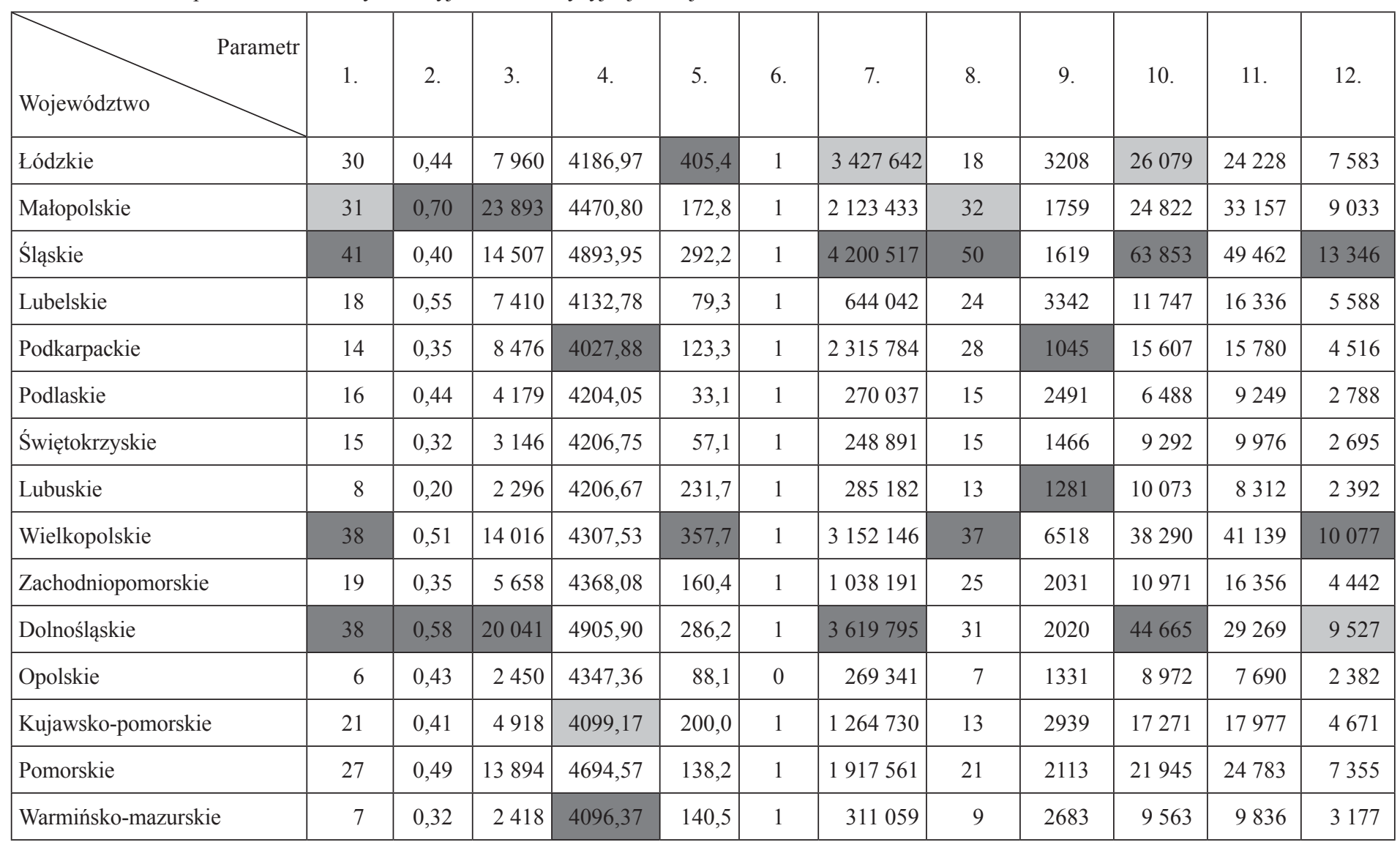

Źródło: opracowanie własne na podstawie danych GUS-u. 
Na rys. 2 przedstawiono odsetek gmin strefowych do ogółu gmin w poszczególnych województwach.

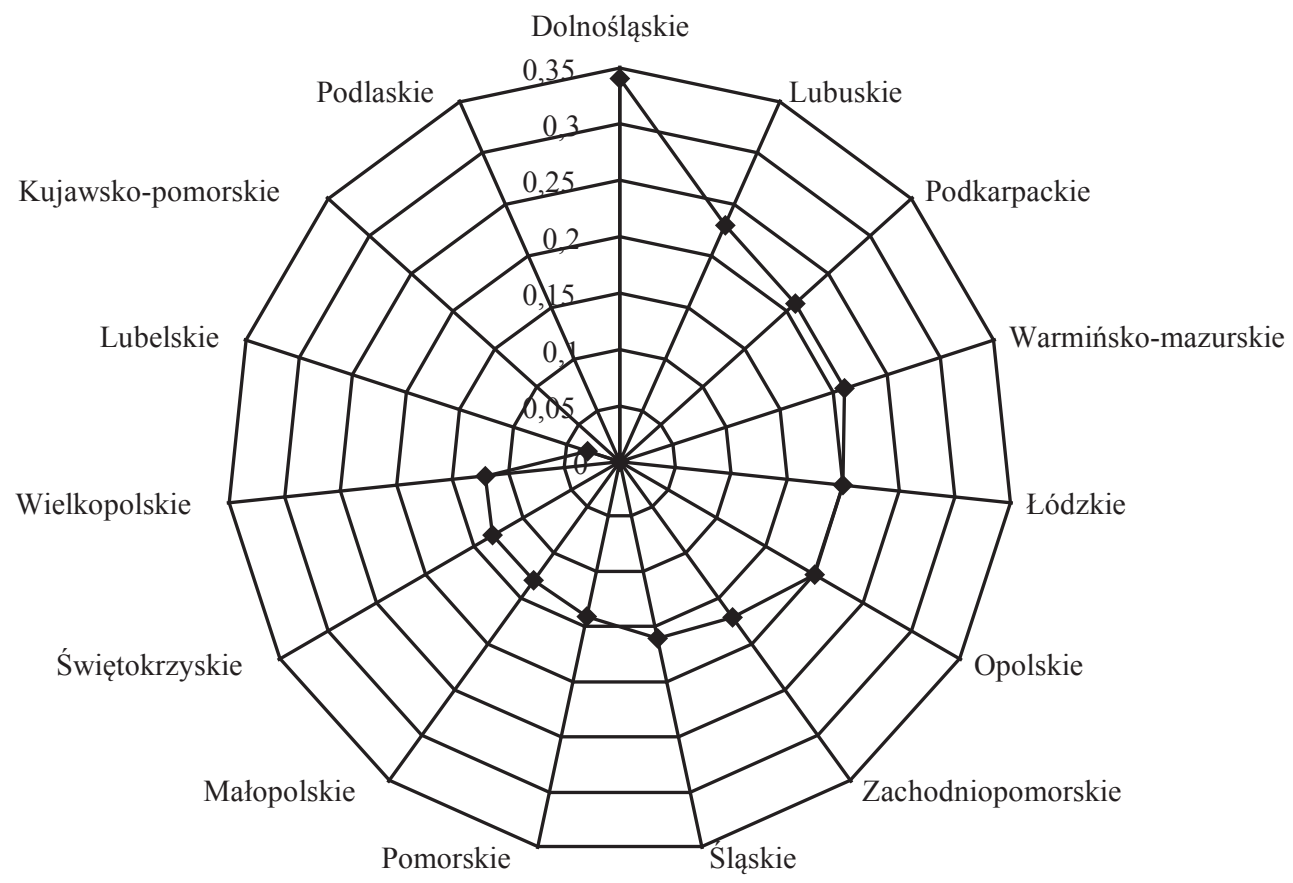

Rys. 2. Udział gmin, w których zlokalizowane są specjalne strefy ekonomiczne, w ogólnej liczbie gmin w województwach Polski

Źródło: opracowanie własne.

Ostatnim etapem analizy było obliczenie współczynnika korelacji między liczbą lokalizacji stref ekonomicznych na terenie województwa a liczbą zdobytych punktów w ocenie atrakcyjności. Parametr wyniósł 0,67 , co potwierdza istnienie zależności.

\section{Zakończenie}

Na podstawie analizy udało się wstępnie potwierdzić tezę, że najwięcej podstref zlokalizowanych jest w regionach najbardziej atrakcyjnych. Cele, dla których powstawały strefy, osiągnięto więc tylko częściowo. Wysoki poziom pomocy regionalnej w strefach nie był w stanie przyciągnąć inwestorów na tereny słabsze. Wybierali oni te o wysokiej atrakcyjności. Tworzenie stref wokół ośrodków miejskich i dużych aglomeracji pogłębiało różnice między regionami. Więcej podstref lokalizowanych jest w centralnej i południowo-zachodniej Polsce, w której infrastruktura 
oraz kapitał ludzki jest na wyższym poziomie. Wschodnia Polska odnotowuje znacznie mniejszą ilość podstref jak i też słabszy poziom rozwoju. Cele, dla których tworzono strefy, a obecne efekty ich funkcjonowania są istotnie rozbieżne. Efekt biegu jałowego znacznie się powiększa. Wskazuje on na to, że inwestycje w określonym regionie powstałyby niezależnie od preferencyjnych warunków. Pomoc publiczna stanowi więc jedynie dodatkową, niekonieczną korzyść inwestora. Bardziej pożądane są pozostałe wartości dodane, takie jak: jakość kapitału ludzkiego, poziom rozwoju infrastruktury, innowacje, instytucje otoczenia biznesu, a nawet dostęp do usług rekreacyjnych, szkolnictwa, opieki medycznej. Przyszłość stref nie jest więc jednoznaczna. Coraz większy udział przypada sektorowi prywatnemu, który stanowi ważną grupę nacisku na ustanawianie nowych podstref na obszarach dogodnych dla inwestora. Strefy przestały spełniać zadanie wyrównywania poziomów rozwoju regionów, jednakże w długim okresie poprawiają atrakcyjność i konkurencyjność inwestycyjną. Przestało być to jednak głównym motywem powoływania podstref, a pozostało jedynie efektem ubocznym działań inwestorów.

Pamiętać jednak należy o wpływie na lokalizację podstref wielu innych czynników, których nie wzięto pod uwagę do badania. Wskazane byłoby podkreślić znaczenie dysproporcji przestrzennych w rozwoju samych regionów. Stają się one motywem do ustanawiania podstref $\mathrm{w}$ gminach słabszych w celu wyrównania różnic na obszarze całego województwa. Potwierdzać by to mogło zasadność istnienia podstref w województwach najbardziej atrakcyjnych, w których występują gminy o niskim poziomie rozwoju. Kolejnym wnioskiem jest słuszność zbadania wpływu poszczególnych podstref na konkretne gminy, by móc potwierdzić postawioną tezę oraz zaobserwować efekty istnienia podstref $\mathrm{w}$ gminach słabszych. W tym celu podjęte zostaną bardziej szczegółowe analizy.

\section{Literatura}

Ajchel M., 2016, Preferencyjne opodatkowanie działalności gospodarczej na terenie Specjalnych Stref Ekonomicznych, Annales Universitatis Mariae Curie-Skłodowska, nr 1, Lublin.

Ambroziak A., 2009, Krajowa pomoc regionalna $w$ specjalnych strefach ekonomicznych $w$ Polsce, Szkoła Główna Handlowa w Warszawie, Warszawa.

Brdulak J., 1999, Specjalne strefy ekonomiczne (SSE) i wolne obszary celne (WOZ) jako czynnik ksztattowania konkurencyjności przedsiębiorstw, Instytut Funkcjonowania Gospodarki Narodowej, Warszawa.

Domański B., Gwosdz K. (red.), 2005, Dziesięć lat doświadczeń pierwszej polskiej specjalnej strefy ekonomicznej. Mielec 1995-2005, Mielec.

Jurkiewicz Z., 2015, Specjalne strefy ekonomiczne jako narzędzie zwiększania atrakcyjności Polski, [w:] Wspótczesne instrumenty innowacji. Zarzadzanie operacyjne w teorii i praktyce organizacji biznesowych, publicznych i pozarzadowych, WSZiP, Wałbrzych, t. 36.

Kryńska E. (red.), 2000, Polskie specjalne strefy ekonomiczne, Wydawnictwo Naukowe Scholar, Warszawa. 
Lichota W., 2016, Efektywność finansowa specjalnych stref ekonomicznych, Gospodarka Narodowa, nr 1.

Nowakowska J., 2009, Preferencyjna polityka podatkowa $w$ specjalnych strefach ekonomicznych a budzet lokalny, Ekonomia, nr 22, Warszawa.

Przewodnik po specjalnych strefach ekonomicznych w Polsce, 2009, KPMG, Warszawa.

Ustawa z dnia 16 listopada 2000 r. o zmianie ustawy o specjalnych strefach ekonomicznych oraz o zmianie niektórych ustaw, DzU 2000, nr 117, poz. 1228.

Ustawa z dnia 20 października 1994 r. o specjalnych strefach ekonomicznych, DzU 1994, nr 123, poz. 600 . 